\title{
Methane and Nitrous Oxide Productions and Community Structure of Methanogenic Archaea in Paddy Soil of South Sulawesi, Indonesia
}

\author{
OSLAN JUMADI ${ }^{*}$ AND KAZUYUKI INUBUSHI ${ }^{2}$ \\ ${ }^{\prime}$ Department of Biology, Faculty of Mathematics and Natural Science, Universitas Negeri Makassar, \\ Jalan Daeng Tata Raya, Parangtambung, Makassar, South Sulawesi 90224, Indonesia; \\ ${ }^{2}$ Graduate School of Horticulture, Chiba University, Matsudo, Chiba 271-8510, Japan
}

\begin{abstract}
The potential of methane and nitrous oxide productions and community structure of methanogenic archaea has been characterized by incubation studies and PCR-DGGE approaches, respectively. The results showed that addition of straw into the soil was the most important factor that influenced $\mathrm{CH}_{4}$ production in this incubation experiment, while $\mathrm{N}_{2} \mathrm{O}$ production was observed higher in soil without straw amendment under saturated condition. Most of the clone sequences revealed from DGGE band was associated with a archaea lineage, Methanocellales ord. nov (Rice Cluster I). Other sequences belong to Methanomicrobiales, Methanosaetales, and Rice Cluster 2 (RC-2). The study also showed that the hydrogenotrophic methanogens were the dominant members in methanogenic archaea community obtained from tropical paddy field soil, while acetoclastic methanogens present in relatively minor quantity in the soil.
\end{abstract}

Key words: $\mathrm{CH}_{4}$, methanogenic archaea, $\mathrm{N}_{2} \mathrm{O}$, paddy soil

Telah dilakukan karakterisasi struktur komunitas archaea metanogenik dari tanah persawahan dengan metode PCR-DGGE serta potensinya dalam menghasilkan gas metana dan nitrous oksida secara teknik inkubasi. Hasil memperlihatkan bahwa pemberian jerami merupakan faktor yang sangat mempengaruhi dalam produksi gas metana, sementara produksi gas nitrous oksida tertinggi pada tanah berkondisi air jenuh tanpa jerami. Secara umum klon sekuen dari DGGE band teraffiliasi dengan archaea Methanocellales ord. nov (Rice Cluster I). Sekuen lainya adalah Methanomicrobiales, Methanosaetales, dan Rice Cluster 2 (RC-2). Studi ini juga menunjukkan bahwa kelompok metanogen hidrogenotrofik adalah struktur komunitas archaea metanogen yang dominan, sedangkan komunitas metanogen asetoklastik merupakan struktur komunitas yang minor pada tanah persawahan di Maros, Sulawesi Selatan.

Kata kunci: archaea metanogen, $\mathrm{CH}_{4}, \mathrm{~N}_{2} \mathrm{O}$, tanah sawah

Global atmospheric concentration of methane $\left(\mathrm{CH}_{4}\right)$ and nitrous oxide $\left(\mathrm{N}_{2} \mathrm{O}\right)$ have increased due to natural process, biological processes and also by anthropogenic activities. $\mathrm{CH}_{4}$ concentration in the atmosphere has increased from early 90 s of about 1732 ppb to $1774 \mathrm{ppb}$ in the 2005, and that concentration has increased up to $40 \%$ since pre-industrial time, while the global atmospheric concentration of $\mathrm{N}_{2} \mathrm{O}$ increased from $270 \mathrm{ppb}$ in pre-industrial time to about $319 \mathrm{ppb}$ in 2005 (IPPC 2007a).

More than one third of all $\mathrm{CH}_{4}$ emissions come from soils, as a result of the microbial breakdown of organic compounds in strictly anaerobic conditions. This process occurs in natural wetlands, in flooded rice fields, and in landfills rich in organic matter, as well as in the gut of some species of soil dwelling termites. The rice field and landfill sources make up an important part of anthropogenic methane emissions, which have led to the more than doubled concentration in the

*Corresponding author; Phone:+62-411-840610, Fax :+62411-841504,E-mail: oslanj@gmail.com atmosphere. Analysis of gas trapped in polar ice shows that in the pre-industrial era it was only $c a .0 .7 \mu \mathrm{mol}$ $\mathrm{mol}^{-1}$ (IPPC 2007b).

$\mathrm{CH}_{4}$ is an important component of the global carbon cycle and contributes to enhanced greenhouse effect as well as $\mathrm{N}_{2} \mathrm{O}$. Paddy cultivation is considered as one of the main human-related sources of $\mathrm{CH}_{4}$, and has been predicted that $\mathrm{CH}_{4}$ emission from paddy cultivation will increase as rice production increase by $65 \%$ from end 1990s of $460 \mathrm{Mt} \mathrm{yr}^{-1}$ to $760 \mathrm{Mt} \mathrm{yr}^{-1}$ in 2020 (Neue 1997). $\mathrm{CH}_{4}$ emission from paddy cultivation contributes about 20 to $150 \mathrm{Tg} \mathrm{CH}_{4} \mathrm{yr}^{-1}$ to the global budget (Crutzen 1995). Larger variation in the magnitude of $\mathrm{CH}_{4}$ emission from that source is attributed to soil parameters $(\mathrm{pH}$, redox potential, organic matter content, temperature, clay) or agronomic condition (rice cultivars and farming practices) (Fumoto et al. 2008).

The magnitude of $\mathrm{CH}_{4}$ emission from paddy field reflects the balance between methanogenesis and methanotrophy. $\mathrm{CH}_{4}$ production is the final process in the anoxic microbial degradation pathway in paddy 
field soil, while, methane oxidation occurs at anaerobic-aerobic interface with available oxygen $\left(\mathrm{O}_{2}\right)$ and $\mathrm{CH}_{4}$ concentration. The quantity of $\mathrm{CH}_{4}$ actually emitted depends on both production and oxidation of $\mathrm{CH}_{4}$. Therefore, basic knowledge on the underlying processes is required when designing strategies to mitigate and control $\mathrm{CH}_{4}$ emission from paddy field (Henckel et al. 2000; Bodegom et al.2001).

$\mathrm{CH}_{4}$ is produced by microbial community consisting of various fermenting microorganisms that degrade organic matter and ultimately to acetate, $\mathrm{H}_{2}$ and $\mathrm{CO}_{2}$. The most actual production of $\mathrm{CH}_{4}$ is brought about by methanogenic archaea, which either convert acetate to $\mathrm{CH}_{4}$ and $\mathrm{CO}_{2}$ (acetoclastic methanogenesis) or convert $\mathrm{H}_{2}$ plus $\mathrm{CO}_{2}$ to $\mathrm{CH}_{4}$ (hydrogenotrophic methanogenesis) (Conrad et al. 2006; Sakai et al. 2008). In paddy field soil, the taxonomy of methanogenic archaea members consisted of Methanosaetaceae and Methanosarcinaceae as acetoclastic methanogens type. While, the type of hydrogenotrophic methanogens are including members of Methanomicrobiales, Methanobacteriales, and Rice Cluster1 (RC-I) lineage with new name Methanocellales ord.nov (Sakai et al. 2007 and 2008) .

Not many studies have been conducted to measure the potential of $\mathrm{CH}_{4}$ and $\mathrm{N}_{2} \mathrm{O}$ productions and characterize the responsible microbe of methanogenic archaea from tropical paddy soil. Therefore, the current paper showed the potential of $\mathrm{CH}_{4}$ and $\mathrm{N}_{2} \mathrm{O}$ productions and methanogenic archaea structure from paddy soil in South Sulawesi, Indonesia that approached by incubation experiments and PCR-DGGE, respectively.

\section{MATERIALS AND METHODS}

Soil Sampling and Analysis Descriptions. Soil was sampled in Maros district, south Sulawesi province, Indonesia $\left(5 \mathrm{~m}\right.$ asl., $05^{\circ} 00.419^{\prime} \mathrm{S}$ $\left.119^{\circ} 31.219^{`} \mathrm{E}\right)$, which is a rice-growing area $(6513$ ha). Soil was classified as Typic Haplusterts according to U.S. Soil Taxonomy, 1998. The soil was alluvial type according to Center for Soil and Agro-climate Research, Indonesia, 2000. Soil samples were taken from each micro-plot either before transplanting or after plowing at a depth of $0-15 \mathrm{~cm}$ (plowed layer) and sieved as moist condition through $2 \mathrm{~mm}$ mesh and stored at $4{ }^{\circ} \mathrm{C}$ until soils were used in laboratory incubation experiment. The soil had a $\mathrm{pH}\left(\mathrm{H}_{2} \mathrm{O}\right)$ of 7.22, EC of $0.17 \mathrm{dS} \mathrm{m}^{-1}$, total carbon content of $22.5 \mathrm{~g}-\mathrm{C} \mathrm{kg}^{-1}$, total $\mathrm{N}$ content of $2.30 \mathrm{~g}-\mathrm{N} \mathrm{kg}^{-1}$ dry soil, and $\mathrm{C} / \mathrm{N}$ ratio of 9.78, measured by electrode methods and a $\mathrm{C} / \mathrm{N}$ analyzer (MT 700, Yanaco, Kyoto, Japan), respectively.

\section{Determination of Potential Production of $\mathrm{CH}_{4}$} and $\mathbf{N}_{2} \mathbf{O}$. The Greenhouse gas production potential $\left(\mathrm{CH}_{4}\right.$ and $\left.\mathrm{N}_{2} \mathrm{O}\right)$ of paddy field soil sample were determined by incubation method in the laboratory. A composite portion of 100 grams soil were pre incubated at $30{ }^{\circ} \mathrm{C}$ for seven days in sealed $1000 \mathrm{~mL}$ glass bottle for pre-incubation purpose. The soil samples were then added with inorganic fertilizer (urea) at a rate of $120 \mathrm{mg}-\mathrm{N} \mathrm{kg}^{-1}$. Then, these samples were set as two factorial design with 3 replications, and the first factor with organic amendments (with 1.0 $\mathrm{g}$ of rice straw or without), and the second factor was water regime $(\mathrm{WS}=$ water saturated, $\mathrm{WSS}=$ water saturated plus straw). All soil samples were incubated at $30^{\circ} \mathrm{C}$ and gas in the headspace of each bottle were taken every five days interval to quantify the concentrations of $\mathrm{CH}_{4}$ and $\mathrm{N}_{2} \mathrm{O}$. The concentrations of $\mathrm{CH}_{4}$ and $\mathrm{N}_{2} \mathrm{O}$ in the samples were quantified using gas chromatographs (Shimadzu, GC 14B, Kyoto, Japan) equipped with a flame ionization detector (FID) and an electron capture detector (ECD), respectively. After gases were sampled the bottle stopper were opened for $30 \mathrm{~min}$ to change the air in side the bottle and soils were incubated continually until $35 \mathrm{~d}$.

Means and standard deviations of the data were calculated. Means were compared using the least significant differences $(\mathrm{LSD}=0.05)$ value by SPSS software (Ver.11.0 for windows, SPSS Inc., Chicago, USA).

DNA Extraction and Polymerase Chain Reaction (PCR) Amplification. At the end of incubation $(35 \mathrm{~d})$, soil from surface $(0.5 \mathrm{~cm})$ and subsurface $(1.0 \mathrm{~cm}$ below surface $)$ of each treatment was collected carefully and subjected for extraction of DNA from soil. Soil DNA was extracted using a FastDNA SPIN Kit for soil (Bio 101, Inc. Vista, CA, USA) following the manufacturer's instructions. In this procedure, cell lyses was performed by vigorous shaking in a mini-beadbeater (Biospec product, Wakenyaku, Co., Tokyo, Japan) with intense speed of 4.8 for $30 \mathrm{sec}$. DNA extracts were stored at $-20{ }^{\circ} \mathrm{C}$ before used as a template for subsequent $\mathrm{PCR}$ reaction.

One $\mu \mathrm{L}$ of DNA extract was used as template for PCR amplification with primers 0357F (5'-CCCTAC GGGGCGCAGCAG-3'; Escherichia coli position 340-357) and 0691R (5'-GGATTACARGATTTCAC3`; E.coli position 707-691) (Watanabe et al. 2004, 2006 and 2007). The primer pair was used for PCR amplification of 16S rRNA gene fragment of methanogenic archaea. PCR amplification was performed in a total volume of $50 \mu \mathrm{L}$ reaction mixture 
containing $5 \mu \mathrm{L}$ of 10x Ex Taq buffer (20 $\left.\mathrm{mM} \mathrm{Mg}^{2+}\right), 4$ $\mu \mathrm{L}$ of dNTP mixture with final concentration of 2.5 $\mathrm{mM}$ of each, $0.5 \mu \mathrm{L}$ of each primers $(80 \mathrm{pmol} \mu \mathrm{L})$ and $0.3 \mu \mathrm{L}$ of Ex Taq DNA polymerase $\left(5 \mathrm{U}_{\mu} \mathrm{L}^{-1}\right.$, a hot start version) and made to volume using a sterile distilled water (Otsuka Pharm., Japan). Ex Taq DNA polymerase, dNTP mixture, and 10x Ex Taq buffer were purchased from Takara Bio Inc. Shiga, Japan.

The PCR reaction was run using a DNA thermocycler (Takara Bio Inc. model TP600, Japan). The thermal profile regime was a hot start at $94^{\circ} \mathrm{C}$ for 3 min (denaturation) and 35 cycles at $94{ }^{\circ} \mathrm{C}$ for $1 \mathrm{~min}$, followed by $53{ }^{\circ} \mathrm{C}$ for $1 \mathrm{~min}$, and then $72^{\circ} \mathrm{C}$ for $2 \mathrm{~min}$. A final extension step was at $72{ }^{\circ} \mathrm{C}$ for $5 \mathrm{~min}$. The quality of the PCR products were tested by running $5 \mu \mathrm{L}$ of it on a $2 \%$ agarose for $30 \mathrm{~min}$ at $100 \mathrm{~V}$ in $1 \mathrm{X}$ TAE and visualized by UV transillumination (ATTO printgraph, model AE-6932) after staining with ethydium bromide for $30 \mathrm{~min}$ and washing with distilled water.

Denaturing Gradient Gel Electrophoresis (DGGE), Sequencing, and Phylogenetic Analysis. DGGE analysis was performed on the D-Code system (Bio-Rad, Hercules, Calif.). PCR products were applied directly into $7 \%(\mathrm{wt} / \mathrm{vol})$ polyacrylamide gels in 1X TAE (40 mM Tris base (pH 7.2), $20 \mathrm{mM}$ acetic acid, $0.5 \mathrm{M}$ EDTA $1 \mathrm{mM}$ ) with $35-60 \%$ denaturing gradient (urea and formamide). One hundred percent denaturing acrylamide was defined as $7 \mathrm{M}$ urea and $40 \%$ formamide. A top gel without denaturant was cast above the denaturing gel before the polymerization started. $25 \mu \mathrm{L}$ of PCR products were loaded into each lane and run at $60 \mathrm{~V}$ for 14 hours at constant temperature of $60^{\circ} \mathrm{C}$ and visualized after staining with ethydium bromide for $30 \mathrm{~min}$ and washed twice with distilled water.

Prominent DGGE bands were excised from the gel with a sterile razor blade and placed in $1.5 \mathrm{~mL}$ plastic tube with $50 \mu \mathrm{L}$ of sterile distilled water and vortex gently for 5 seconds and then incubated overnight at 4 ${ }^{\circ} \mathrm{C}$. After centrifugation at $2000 \mathrm{rpm}$ for 10 seconds, $1 \mu \mathrm{L}$ of liquid was used as template for PCR reactions performed under the conditions described above and then separated on DGGE again after only a single band appeared. The single band was excised as mentioned above, and then subjected as template for PCR reactions performed under the conditions described before without GC clamp on forward prime. The quality of DNA recovered from gel acrylamide after PCR reactions were determined on agarose gel electrophoresis as explained above.
The remaining PCR products were purified using Suprex $^{\mathrm{TM}}$ (Takara Bio. Inc. Shiga, Japan) according to manufacturer's instructions. One $\mu \mathrm{L}$ of purified PCR product was used as a template for cycle sequencing reaction performed with a DNA sequencing kitBigDye $^{\mathrm{TM}}$ Terminator v3.0 (Applied Biosystem, Foster City, CA, USA) with forward and reserve primers run separately. The sequencing reaction was performed for 30 cycles at $95^{\circ} \mathrm{C}$ for $30 \mathrm{sec}$ (denaturation), at $60^{\circ} \mathrm{C}$ for $30 \mathrm{sec}$ (annealing) and at $75^{\circ} \mathrm{C}$ for $95 \mathrm{sec}$ (extension). Prior to DNA sequence analyses with an ABI 3100 genetic analyzer (Applied Biosytems, USA) the reaction products were purified with Centri-Sep Columns (Princeton Separation, NJ) following manufacturer's instructions.

Phylogenetic relationships of the aligned sequences were inferred using the neighbor-joining (Saitou and Nei 1987). A bootstrap analysis with 1000 replicates was made for all database sets to evaluate the stability of phylogeny (Felsenstein 1985). The evolutionary distances were computed using the Kimura 2-parameter method (Kimura 1980). Phylogenetic analyses were conducted in MEGA 4 (Tamura et al. 2007). The nucleotide sequences in this study have been deposited in the DNA databank of Japan (DDBJ, URL: http://www.ddbj.nig.ac.jp/) under accession no. AB 440226 through AB440235.

\section{RESULTS}

Change in production of greenhouse gas $\left(\mathrm{CH}_{4}\right.$ and $\mathrm{N}_{2} \mathrm{O}$ ) during soil incubation is shown in Fig 1A and B, respectively. The production of $\mathrm{CH}_{4}$ with straw amendment under flooded condition was significantly higher than the other treatments (Fig 1A). The straw amended soil under flooded condition had produced $20.6 \mu \mathrm{g} \mathrm{CH}_{4}-\mathrm{C} \mathrm{g}^{-1}$ dry soil ${ }^{-1}$ after 5 days of incubation and its almost ten times higher compared with water saturated $\left(2.6 \mu \mathrm{g} \mathrm{CH}_{4}-\mathrm{Cg}^{-1}\right.$ dry soil $\left.{ }^{-1}\right)$ and peaked on 10 day incubation (103 $\mu \mathrm{g} \mathrm{CH}_{4}-\mathrm{C} \mathrm{g}^{-1}$ dry soil $\left.{ }^{-1}\right)$, then gradually declined thereafter. Meanwhile, $\mathrm{CH}_{4}$ productions in the other treatments were almost negligible.

On the other hand, the $\mathrm{N}_{2} \mathrm{O}$ production was observed higher in soil without straw amendment and under unflooded water condition at $5 \mathrm{~d}$ incubation compared to the other treatments, and then rapidly decreased on $10 \mathrm{~d}$ incubation. After $15 \mathrm{~d}$ of incubation small amount of $\mathrm{N}_{2} \mathrm{O}$ was produced and then decline after the end of incubation (Fig 1B). Soil incubated with straw amendment and under saturated water 
condition produced small amount of $\mathrm{N}_{2} \mathrm{O}$ at $5 \mathrm{~d}$ of incubation and then declined thereafter. The other treatments were almost not producing $\mathrm{N}_{2} \mathrm{O}$ during the incubation period.

The community structure of methanogenic archaea in paddy field soil in tropical region such as Indonesia were investigated with PCR-DGGE method affiliated with a clone lineage of archaea, Rice Cluster I (RC-I). Other sequences belong to Methanomicrobiales, Methanosaetales and Rice Cluster 2 (RC-2) (Fig 3). All paddy field soil incubation exhibited a high frequency (70\%) of sequences characteristic of hydrogenotrophic methanogens (Methanocellales (RC-I) and Methanomicrobiales), whereas the frequency of

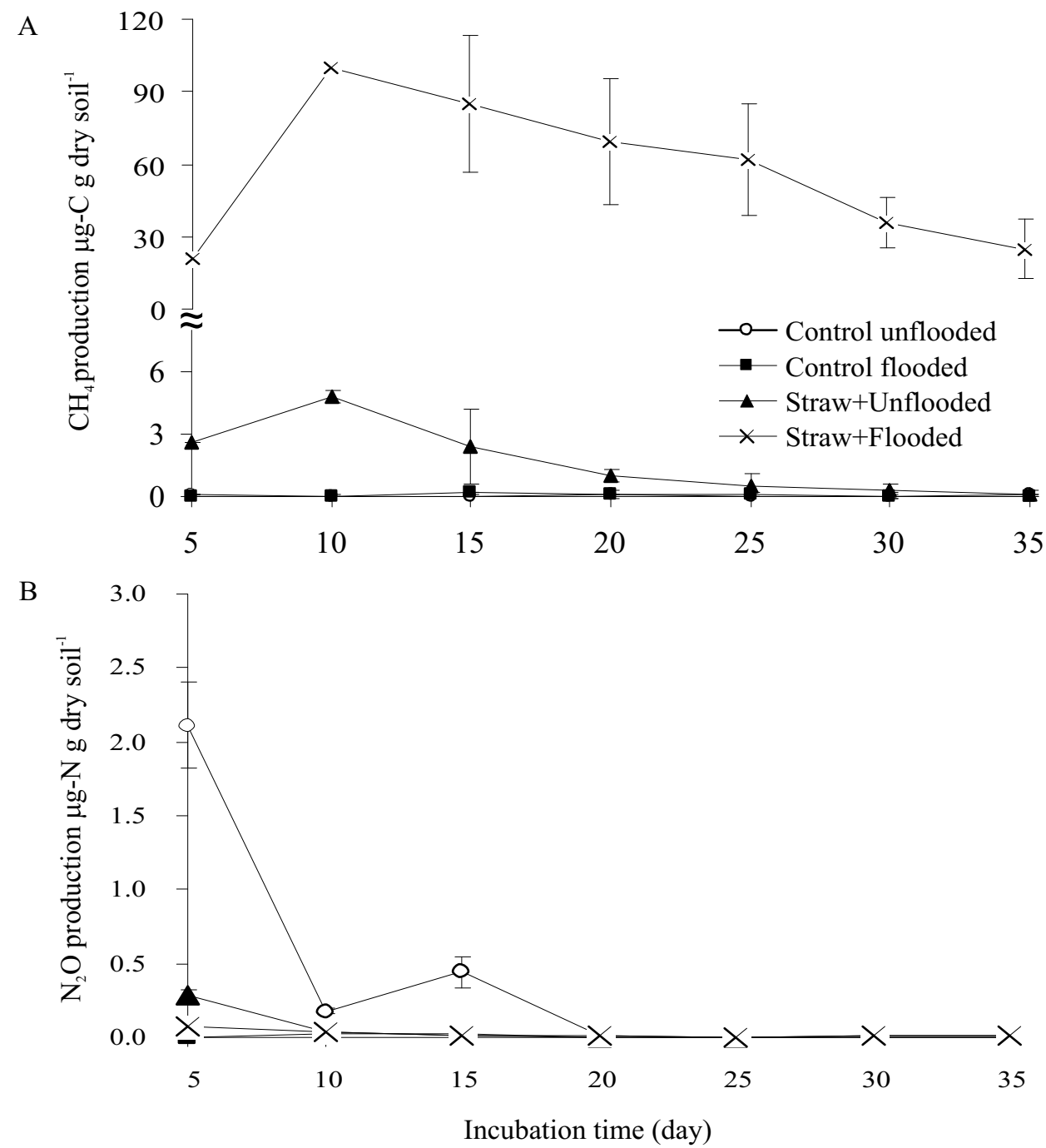

Fig 1 Change in production of (A) $\mathrm{CH}_{4}$ and (B) $\mathrm{N}_{2} \mathrm{O}$ during incubation of soil samples. The error bars indicate the standard deviation of the results.

approaches with a primer set (0357F-GC/0691R). The pair primer is suitable for investigating methanogenic archaeal community in paddy field soil. Extraction of the soil DNA revealed that from soils incubated after $35 \mathrm{~d}$ at different layer indicated fine reproducibility of the DGGE banding patterns (Fig 2). The DGGE band showed that no apparent change of archaea community structure in all soil treated, even in the soil amended with straw which had more than 30 times higher $\mathrm{CH}_{4}$ production potential (Fig 1A).

Most clones were, revealed from the DGGE band, acetoclastic methanogenesis (Methanosaetales and Methanosarcinales) was as low as $10 \%$.

\section{DISCUSSION}

The production of $\mathrm{CH}_{4}$ during incubation was much higher in flooded condition with straw amendment due to the pathway of $\mathrm{CH}_{4}$ formation. This $\mathrm{CH}_{4}$ production pattern is a typical $\mathrm{CH}_{4}$ kinetics. This is similar to the results found in comparable experimental systems under continuous production for several 


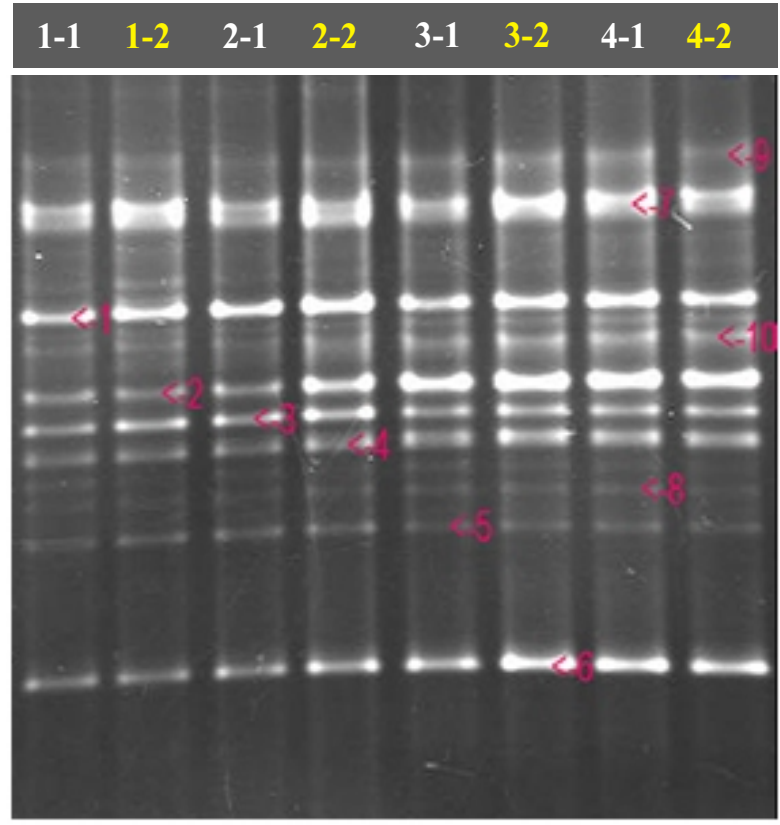

Fig 2 Denaturing Gradient Gel Elecrophoresis (DGGE) band patterns of PCR products with 0357F-GC and 0691R primer. Lane 1-1: Without straw saturated-surface soil; Lane 1-2: Without straw saturated-subsurface soil; Lane 2-1: Without straw flooded-surface soil; Lane 2-2: Without straw saturated-subsurface soil; Lane 3-1: Straw saturated-Surface soil; Lane 3-2: Straw saturated-Subsurface soil; Lane 4-1: Straw flooded -surface soil; Lane 4-2: Straw flooded -subsurface soil.

weeks as described previously (Frenzel et al. 1996; Yagi et al. 1997; Inubushi et al. 1992 and 2002). Flooded condition allows the soil environment to become anoxic, which is the required environmental condition for the methanogens to produce $\mathrm{CH}_{4}$ by converting substrate acetate or $\mathrm{H}_{2}$ plus $\mathrm{CO}_{2}$.

Acetate or $\mathrm{H}_{2}$ plus $\mathrm{CO}_{2}$ are sub-products of various fermenting microorganisms that degrade straw. Therefore, the $\mathrm{CH}_{4}$ production was not detected in soil incubated without straw even under flooded condition, while small amount of $\mathrm{CH}_{4}$ production occurred during the early stages incubation in saturated soil condition with straw amendment, which then decreased to almost nil value at $35 \mathrm{~d}$ (Fig 1A). Hence, the incorporation of straw into the soil was the most important factor that influenced $\mathrm{CH}_{4}$ production in this incubation experiment.

Conrad and Klose (2006) reported that the addition of straw enhanced the intermediate production of $\mathrm{H}_{2}$ and acetate that served as the methanogenic substrates. Also some fatty acid was determined increased transiently upon straw addition. They also suggested that the copy number of bacteria and archaea $16 \mathrm{~S}$ rRNA genes increased at the end of their experiment. In addition, under steady state condition, cellulose would methanogenically be degraded to $50 \% \mathrm{CO}_{2}+$ $50 \% \mathrm{CH}_{4}$, while methanogenesis from acetate and $\mathrm{H}_{2}$ plus $\mathrm{CO}_{2}$ theoretically contribute $>67 \%$ and $<33 \%$ to total $\mathrm{CH}_{4}$ production, respectively (Conrad et al. 2002). Chin et al. (2003) suggested that $\mathrm{CH}_{4}$ was initially produced from reduction of $\mathrm{CO}_{2}$ resulting in the accumulation of acetate and at this stage the relative abundance of acetoclastic methanogens was low. Later on, the production of $\mathrm{CH}_{4}$ was originated from acetate by $40 \%$ with relative increase of population of Methanosarcina spp.

Lueders and Freidrich (2000) observed that the population structure of methanogenic archaea remained remarkably constant over time after flooding in the paddy field soil even though they observed a shift in the activity of the Methanosarcina-like populations. Similar observation by Watanabe et al. (2006) showed that the community structure of methanogenic archaea in Japanese paddy field soil did not change throughout a year even at the mid-season drainage and upland cropping time. However, Sugano et al. (2005) suggested that methanogenic archaea communities involved in the decomposition of rice straw under flooded condition were affected by mid-season drainage irrespective of plant part on the rice straw (leaf sheath or leaf blade). In addition, using different sources of soil samples, Nicol et al. (2003) showed a change of the methanogenic archaea community in the managed grassland rhizosphere soil compared to the natural one after incubated for $28 \mathrm{~d}$ in anaerobic condition. 


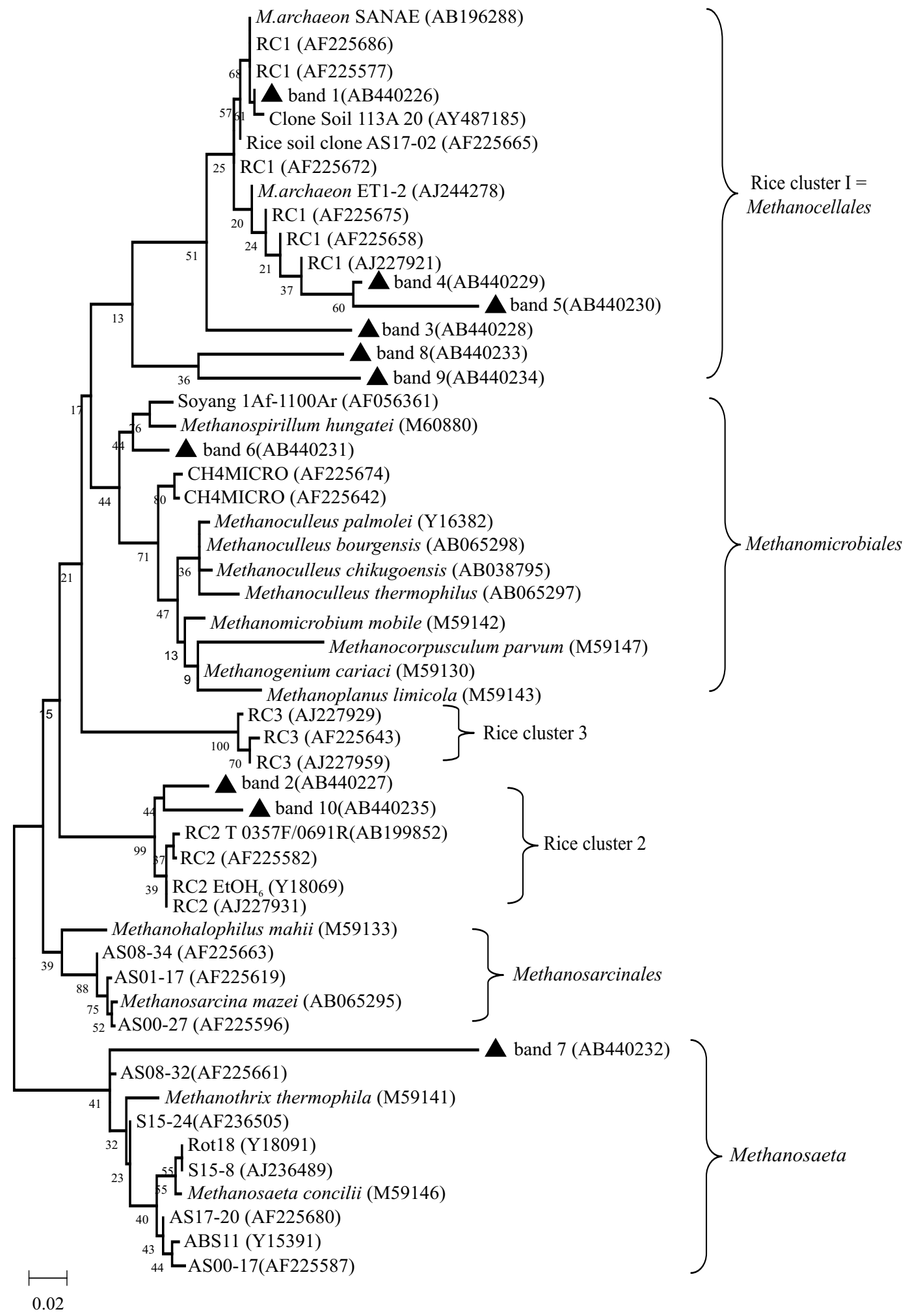

Fig 3 Phylogenetic tree based on partial nucleotide acid retrieved from the DGGE bands. Bands obtained from this study are marked with triangle shape $(\boldsymbol{\Delta})$. Values in the figures are bootstrap values, and branching corresponding to partitions reproduced in less than $50 \%$ bootstrap replicated are collapsed. The scale of bar indicates 2 changes per 100 nucleotide acid.

The present work indicated that soil incubated at flooded or saturated condition with and without straw did not alter the community structure of methanogenic archaea at different layers of soil sampled. But, in another work that used the same soil DNA extraction, we determined a few changes of bacteria community structure by PCR-DGGE using pairs of universal bacteria primers of $341 \mathrm{f} / 534 \mathrm{r}$ (data not shown).

The explanation of these results might be due to the soil chemical properties during incubation that have 
favorable environment for the methanogenic archaea communities to survive under all the treatments used. Meanwhile, the fermenting microorganisms (dominantly bacteria) might have a shift of population during the straw degradation. Another possibility was the incubation time was not long enough to induce the appearance of other methanogenic population particularly acetoclastic methanogenesis type as suggested by Kruger et al. (2005).

The methanogenic archaea is also known to tolerate higher oxygen and have some enzymes to detoxify oxygen-related toxic compounds, hence, methanogens are proposed to be more resistant to $\mathrm{O}_{2}$ (Lueders and Friedrich 2000; Erkel et al. 2006). The study also suggested that the production of $\mathrm{CH}_{4}$ by methanogenic archaea seems not correlated with the band patterns but mainly due to the soil environments that enhanced methanogenesis such as in soil-flooded with straw amendments.

Similar to other reports, this study showed that hydrogenotrophic methanogens were dominant members in methanogenic archaea community retrieved from temperate paddy field soil (Lueders and Friedrich 2000; Sugano et al. 2005; Watanabe et al. 2006), while acetoclastic methanogens were relatively minor in abundance in the paddy field soil. We speculated that the members of community structure of hydrogenotrophic methanogens, Methanocellales (RC-I), was dominant in the soil used that took from the tropic region, of Indonesia.

The Methanocellales (RC-I) lineage has been found in almost every paddy field soil samples, particularly on rice roots and also detected dominant appeared in the prolonged incubation at $50{ }^{\circ} \mathrm{C}$ (Chin et al. 2003; Conrad et al. 2006; Wu et al. 2006). In addition, due to the capacities and a unique set of antioxidant enzyme and DNA repair, Methanocellales should have a competitive superiority over the other hydrogenotrophic methanogens in rice rhizosphere and other methanogenic environments with oxic episodes, such as boreal peat lands and tropic soils (Erkel et al. 2006).

More over Ramakrishnan et al. (2001) also reported that Methanocellales or RC-I occurred in such soils from various geographic regions. In addition, $\mathrm{Lu}$ and Conrad (2006) reported that Methanocellales (RCI) were found to be highly active and play key role in $\mathrm{CH}_{4}$ production from plant-derived carbon and, therefore, the group was responsible for microbial $\mathrm{CH}_{4}$ emission from paddy field (Erkel et al. 2006).

Methanocellales (RC-I) has been identified as a different genotypic group from the orders of Methanosarcinales and Methanomicrobiales due to low sequence similarity value with those of the two aforementioned orders (Großkopf et al. 1998). The physiological properties of this members is also not similar with members of the Methanosarcinales and Methanomicrobiales, which utilize acetate and simple methylated compound, while this member of Methanocellales (RC-I) use $\mathrm{H}_{2}$ plus $\mathrm{CO}_{2}$ to produce $\mathrm{CH}_{4}$ (Conrad 1996; Erkel et al.2006; Sakai et al. 2008).

Two bands (band 2 and 10) were revealed as rice cluster 2 (RC-2). The RC-2 were placed between the orders Methanosarcinales and Methanomicrobiales (Fig 3), where it has also been reported by Großkopf et al. (1998) based on the level of rDNA similarity to these orders. Only 1 band of each member of Methanosaetales and Methanomicrobiales was retrieved from DGGE as band 7 and band 6, respectively, while no member of Methanosarcinales or Rice cluster 3 were identified from DGGE band (Fig 2), Großkopf et al. (1998) and Fey and Conrad (2000) reported that Methanosaetales was hardly detected in roots but commonly appeared in anoxic bulk soil, especially at low acetate concentration. Since the paddy field soils used was taken as a bulk soil before transplanting time, it is also possible that member of Methanosaetales was detected in soil used.

$\mathrm{N}_{2} \mathrm{O}$ gas is emitted in paddy soils via nitrification and denitrification or nitrate accumulated when soils have an aerobic surface layer and anaerobic condition, respectively (Akiyama et al. 2005; Inubushi et al. 1996; Jumadi et al. 2008). The main pathway of $\mathrm{N}_{2} \mathrm{O}$ production from paddy-soil system depends on the soil water status. Therefore, current study also shows that $\mathrm{N}_{2} \mathrm{O}$ production in almost neglected monitored even in closed system experiment. In addition, at saturated condition the $\mathrm{N}_{2} \mathrm{O}$ released by denitrification increase with decreasing $\mathrm{O}_{2}$ partial pressure. Therefore, after five days incubation $\mathrm{N}_{2} \mathrm{O}$ production at control flooded was monitored higher and then decrease thereafter substantially to lower concentration. That might be due to the availability of $\mathrm{NO}_{3}$ and reduced $\mathrm{O}_{2}$ concentration.

The study also showed that $\mathrm{N}_{2} \mathrm{O}$ emissions were suppressed in all the treatments and it could be predicted that $\mathrm{N}_{2} \mathrm{O}$ emission was almost not existent. The field scale studies in the tropical region of Indonesia showed that $\mathrm{N}_{2} \mathrm{O}$ was almost not emitted. However, in incubation experiment the $\mathrm{N}_{2} \mathrm{O}$ production by nitrification occurred even in moist soil (50-70\% of soil moisture) and it was also influenced by the number of responsible microbe such as ammonium oxidation 
bacteria and nitrite oxidation bacteria (Hadi et al. 2008; Inubushi et al. 2003; Jumadi et al. 2005; Jumadi et al. 2008b; Jumadi et al. 2012).

The study showed that the hydrogenotrophic methanogens were dominant members in methanogenic archaea community obtained from tropical paddy field soil of south Sulawesi Indonesia, while, acetoclastic methanogens were relatively minor presence in the soil sample. Study also suggested that $\mathrm{N}_{2} \mathrm{O}$ production almost neglected in paddy soil with saturated condition.

\section{ACKNOWLEDGMENTS}

This study was supported by the GHG-SSCP project (S2-3a) of the Global Environment Research Fund by the Ministry of the Environment, Japan. We thank Masatoshi Sonoda (Laboratory Biotechnology of Agroresources) Chiba University for his help in sequences analysis. We also thank to Alimuddin Ali, Abd. Muis, and Muhiddin Pallenari of Biology Department, Universitas Negeri Makassar for soil sampling.

\section{REFERENCES}

Akiyama H, Yan X, Yagi K. 2006. Estimation of emission factors for fertilizerinduced direct $\mathrm{N}_{2} \mathrm{O}$ emission from agricultural soils in Japan: Summary of available data. Soil Sci Plant Nutr. 52(6):774-787. doi: 10.1111/j.1747-0765.2006.00097.x.

Bodegom VP, Stams F, Mollema L, Boeke S, Leffelaar. 2001. Methane oxidation and the competition for oxygen in the rice rhizosphere. Appl Environ Microbiol. 67(8): 3586-3597. doi: 10.1128/AEM.67.8.3586-3597.2001.

Chin KJ, Lueders T, Friedrich MW, Klose M, Conrad R . 2003. Archaeal community structure and pathway of methane formation on rice roots. Microbiol Ecol. 47(1): 59-67. doi: 10.1007/s00248-003-2014-7.

Conrad R, Klose M, Claus P. 2002. Pathway of $\mathrm{CH}_{4}$ formation in anoxic rice field soil and rice roots determined by $13 \mathrm{C}$-stable isotope fractionation. Chemosphere 47(8): 797-806. doi:10.1016/S00456535(02)00120-0.

Conrad R, Klose M. 2006. Dynamic of the methanogenic archaeal community in anoxic rice soil upon addition of straw. Euro J Soil Sci. 57(4): 476-484. doi: 10.1111/j.1365-2389.2006.00791.x.

Crutzen PJ. 1995. On the role of $\mathrm{CH}_{4}$ in atmospheric chemistry: Sources, sink and possible reductions in anthropogenic sources. Ambio. 24: 52-55.

Erkel C, Kube M, Reinhardt R, Liesack W. 2006. Genome of rice cluster I archaea-the key methane producers in the rice rhizosphere. Science 313(5785): 370-372. doi: 10.1126/science. 1127062 .
Fey A, Conrad R. 2000. Effect of temperature on carbon and electron flow and on the archaea community in methanogenic rice field soil. Appl Environ Microbiol. 66(11): 4790-4797. doi:10.1128/AEM.66.11.47904797.2000 .

Felsenstein J. 1985. Confidence limits of phylogenies: An approach using bootstrap. Evolution 39(4): 783-791. doi: $10.2307 / 2408678$.

Frenzel P, Rothfuss F, Conrad R. 1992. Oxygen profiles and methane turnover in a flooded rice microcosm. Biol Fertil Soils. 14(2): 84-89. doi:10.1007/BF00336255.

Fumoto T, Kobayashi K, Li C, Yagi K, Hasegawa T. 2008. Revising a process-based biogeochemistry model (DNDC) to simulate methane emission from rice paddy fields under various residue management and fertilizer regimes. Global Change Biol. 14(2): 382-402. doi: 10.1111/j.1365-2486.2007.01475.x.

Großkopf R, Stubner S, Liesack W. 1998. Novel euryarchaeotal lineages detected on rice roots and in the anoxic bulk soil of flooded rice microcosms. Appl Environ Microbiol. 64(12): 4983-4989.

Hadi A, Jumadi O, Inubushi K, Yagi K. 2008. Mitigation options for $\mathrm{N}_{2} \mathrm{O}$ emission from a corn field in Kalimantan, Indonesia. Soil Sci Plant Nutr. 54(4). doi: 10.1111/j.1747-0765.2008.00280.x.

Henckel T, Roslev P, Conrad R. 2000. Effects of $\mathrm{O}_{2}$ and $\mathrm{CH}_{4}$ on presence and activity of the indigenous methanotrophic community in rice field soil. Environ Microbiol. 2(6):666-679. doi:10.1046/j.14622920.2000.00149.x.

Inubushi K, Muramatsu, Y, Umebayashi, M. 1992. Influence of percolation on methane emission from flooded paddy soil. Soil Sci Plant Nutr. 63:184-189.

Inubushi K, Naganuma H, Kitahara S. 1996. Contribution of denitrification and autotrophic and heterotrophic nitrification to nitrous oxide production in andosols. Biol Fertil Soils. 23:292-298. doi: 10.1007/BF00335957.

Inubushi K, FurukawaY, Hadi A, Purnomo E, Tsuruta H. 2003. Seasonal change of $\mathrm{CO}_{2}, \mathrm{CH}_{4}$ and $\mathrm{N}_{2} \mathrm{O}$ fluxes in relation to land-use change in tropical peatlands located in coastal area of South Kalimantan. Chemosphere 52(3): 603-608. doi:10.1016/S0045-6535(03)00242$\mathrm{X}$.

Inubushi K, Sugii H, Watanabe I, Wassmann R. 2002. Evaluation of methane oxidation in rice plant-soil system. Nutr Cycl Agroecos. 64(1): 71-77. doi:10.1023/A:1021136431176.

IPCC. 2007a. Summary for policymakers. In: Climate Change 2007: The physical Science Basis. Contribution of working group I to the fourth assessment report of Intergovernmental Panel on Climate Change. Cambridge: Cambridge University Press.

IPCC. 2007b. Technical Summary. In: Climate Change 2007: Mitigation. Contribution of Working Group III to the Fourth Assessment Report of the Intergovernmental Panel on Climate Change. Cambridge: Cambridge University Press.

Jumadi O, Hala Y, Inubushi K. 2005. Production and 
emission of nitrous oxide and responsible microorganisms in upland soil in Indonesia. Soil Sci Plant Nutr. 51(5):693-696. doi:10.1111/j.17470765.2005.tb00093.x.

Jumadi O, Hala Y, Muis A, Ali A, Palennari M, Yagi K, Inubushi K. 2008a. Influences of chemical fertilizers and a nitrification inhibitor on greenhouse gas fluxes in a Corn (Zea mays L.) field in Indonesia. Microbes Environ. 23(29-34). doi:10.1264/jsme2.23.29.

Jumadi O, Hala Y, Anas I, Ali A, Sakamoto K, Saigusa M, Yagi K, Inubushi K. 2008b. Community structure of ammonia oxidizing bacteria and their potential to produce nitrous oxide and carbon dioxide in acid tea soils. Geomicrobe J. 25(7-8). doi:10.1080/01490450802402943.

Jumadi O, Ali A, Hala Y, Muis A, Yagi K, Inubushi K. 2012. Effect of controlled water level on $\mathrm{CH}_{4}$ and $\mathrm{N}_{2} \mathrm{O}$ emissions from rice fields in Indonesia. Tropical Agri Develop. Vol. 56(57) (in press).

Kimura M. 1980. A simple method for estimating evolutionary rate of base substitutions through comparative studies of nucleotide sequences. J Mol Evol. 16(2): 111-120. doi: 10.1007/BF01731581.

Kruger M, Frenzel P, Kemnitz D, Conrad R. 2005. Activity, structure and dynamic of the methanogenic archaea community in a flooded Italian rice field. FEMS Microbiol Ecol. 51(3):323-331. doi: 10.1016/j.femsec.2004.09.004.

Leuders T and Friedrich M. 2000. Archaeal population dynamic during sequential reduction processes in rice field soil. Appl Environ Microbiol. 66(7): 2732-2742. doi: 10.1128/AEM.66.7.2732-2742.2000.

Lu Y, Conrad R. 2006. In situ stable isotope probing on methanogenic archaea in rice rhizosphere. Science 309(5737): 1088-1090. doi:10.1126/science.1113435.

Neue HU, Wassmann R, Lantin RS, Alberto MA CR, Aduna JB, Javellana M. 1996. Factors affecting methane emission from rice fields. Atmos Environ. 30(10): 17511754. doi:10.1016/1352-2310(95)00375-4.

Nicol GW, Glover LA, Prosser JI. 2003. Molecular analysis of methanogenic archaeal communities in managed and natural upland pasture soils. Global Change Biol. 9(10): 1451-1457. doi:10.1046/j.1365-2486.2003.00673.x.

Ramakrishnan B, Lueders T, Dunfield PF, Conrad R, Friedrich MW. 2001. Archaeal community structure in rice soils from different geographical region before and after initiation of methane production. FEMS Microbiol Ecol. 37(2): 175-186. doi: 10.1111/j.1574-6941.2001.tb00865.x.
Saito N, Nei M. 1987. The neighbor-joining method: A new method for reconstructing trees. Mol Biol Evol. 4(4): 406-425.

Sakai S, Imachi H, Sekiguchi Y, Ohashi A, Harada H, Kamagata Y. 2007. Isolation of key methanogens for global methane emission from rice paddy fields: a Novel isolate affiliated with the clone cluster rice cluster I. Appl Environ Microbiol. 73(13): 4326-4331. doi: 10.1128/AEM.03008-06.

Sakai S, Imachi H, Hanada S, Ohashi A, Harada H, Kamagata Y. 2008. Methanocella palucida gen. nov., sp. Nov., a methane-producing archaeon, the first isolate of the lineage 'Rice Cluster I', and proposal of the new archaeal order Methanocellales ord. nov. Int J Sys Evol Microbiol. 58:929-936.

Sugano A, Tsuchimoto H, Cho TC, Kimuta M, Asakawa S . 2005. Succession of methanogenic archaea in rice straw incorporated into a Japanese rice field: estimation by PCR-DGGE and sequence analyses. Archaea 1(6): 391-397. doi:10.1155/2005/582597.

Tamura K, Dudley J, Nei M, Kumar S. 2007. MEGA4: Molecular Evolutionary Genetics Analysis (MEGA) software version 4.0. Mol Biol Evol. 24(8):1596-1599. doi:10.1093/molbev/msm092.

Watanabe T, Asakawa S, Nakamura A, Nagaoka K, Kimura M. 2004. DGGE method for analyzing 16S rDNA of methanogenic archaeal community in paddy field soil. FEMS Microbiol Lett. 232(2):153-163. doi: 10.1016/S0378-1097(04)00045-X.

Watanabe T, Kimura M, Asakawa S. 2006. Coomunity structure of methanogenic archaea in Paddy field soil under double cropping (rice-wheat). Soil Biol Biochem. 38(6): 1264-1274. doi:10.1016/j.soilbio.2005.09.020.

Watanabe T, Kimura M, Asakawa S. 2007. Dynamics of methanogenic archaeal communities based on rRNA analysis and their relation to methanogenic activity in Japanese paddy field soils. Soil Biol Biochem. 39(11): 2877-2887. doi: 10.1016/j.soilbio.2007.05.030.

Wu Xl, Friedrich MW, Conrad R. 2006. Diversity and ubiquity of thermophilic methanogenic archaea in temperate anoxic soils. Environ Microbiol. 37:175186.

Yagi K, Tsuruta H, Minami K. 1997. Possible option for mitigating methane emission from rice cultivation. Nutr Cyc Agroecos. 49(1):213-220. doi:10.1023/A:1009743909716. 